\title{
AKIBAT HUKUM CACAT KEHENDAK TERKAIT HAKIKAT BENDA PADA PERJANJIAN JUAL BELI BATU AKIK BONGKAHAN
}

\author{
Ilham Akbar
}

\begin{abstract}
Abstrak : Perjanjian jual beli batu akik bongkahan adalah suatu perjanjian, dimana pihak yang satu mengikatkan dirinya untuk menyerahkan batu akik bongkahan dan pihak yang lain untuk membayar harga yang telah dijanjikan. Jual beli dianggap telah terjadi diantara kedua belah pihak, seketika setelahnya orangorang tersebut mencapai kata sepakat tentang batu akik bongkahan tersebut dan harganya, meskipun batu akik bongkahan itu belum diserahkan, maupun harganya belum dibayar. Syarat sahnya sebuah perjanjian ada 4 (empat), yaitu : (1) sepakat, (2) cakap, (3) objek tertentu dan (4) kausa yang tidak dilarang. Tidak terpenuhinya syarat pertama dan kedua akibat hukumnya perjanjian dapat dapat dibatalkan dan tidak terpenuhinya syarat ketiga dan keempat akibat hukumnya batal demi hukum. Cacat kehendak dalam perjanjian batu akik bongkahan terjadi ketika terjadi ketidaksesuaian kehendak para pihak pihak karena adanya kesesatan dan/atau penipuan. Hakikat benda batu akik bongkahan terdiri atas jenis, kualitas dan/ atau daerah asalnya. Akibat hukum adanya cacat kehendak ini yaitu : a). perjanjian batal ketika kesepatakan belum tercapai diantara para pihak; b). perjanjian dimohonkan gugatan pembatalan kepada pengadilan ketika kesepakatan sudah tercapai; atau c) perjanjian dimohonkan gugatan pembatalan karena penipuan beserta gugatan ganti rugi ketika kesepakatan yang sudah tercapai terdapat kesengajaan dari salah satu pihak untuk mempengaruhi keputusan pihak lainnya dengan cara melanggar hukum.
\end{abstract}

\section{Pendahuluan}

Letak geografis Indonesia yang berada diantara dua benua yaitu Benua Asia dan Benua Australia serta dua samudra yaitu Samudera Hindia dan Samudera Pasipik juga berada pada daerah khatulistiwa sehingga Indonesia mempunyai kekayaan alam yang sangat beragam, misalnya hutan tropis yang sangat luas, garis pantai yang sangat panjang, pegunungan yang berjejer, minyak bumi dan gas alam yang melimpah serta jenis bebatuaan alam yang berbagai jenis. Menarik untuk diamati adalah keberagaman alam Indonesia yang terakhir tersebut, yaitu bebatuan alam. Bebatuan alam berharga atau mempunyai nilai merupakan sebuah objek bisnis, baik untuk diekspor maupun di dalam negeri. Indonesia salah satu negara yang menghasilkan berbagai batu permata (batu berharga yang berwarna indah seperti intan, berlian, nilam dan sebagainya ${ }^{1}$ ) berkualitas dari jenis yang beragam. Batu akik adalah bagian dari batu permata tersebut. Batu akik (agate) adalah batu berwarna yang dijadikan permata cincin dan sebagainya; Geo

\footnotetext{
1 Pusat Bahasa, Kamus Besar Bahasa Indonesia edisi ketiga (Jakarta: Balai Pustaka, 2005), h. 826
}

batuan kalsedon yang tersusun berlapis-lapis dan berbagai warna ${ }^{2}$ dan memiliki kekerasan dibawah 7 skala mohs ${ }^{3}$ merupakan bebatuan berharga yang banyak terdapat di Indonesia, misalnya batu red borneo (rhodochrosite) dari Martapura, Kabupaten Banjar, Kalimantan Selatan, batu bacan (chrysocolla) dari Ternate, Maluku Utara, batu kecubung (amethyst) dari Kalimantan Tengah dan Barat dan batu kalimaya (opal) dari Banten.

Batu permata ini dijualbelikan tidak hanya dalam bentuk yang sudah jadi berupa batu yang sudah dipoles dan siap atau sudah dipasangkan dengan cincin, kalung atau gelangnya tapi juga dalam bentuk bongkahan (bingkah; gumpalan (tanah dan sebagainya); Geo gumpalan batu dengan garis tengah lebih besar daripada $265 \mathrm{~mm}^{4}$ ), karena batu akik terdiri dari lapisan-lapisan maka kualitas

\footnotetext{
2 Pusat Bahasa, Kamus Besar Bahasa Indonesia edisi ketiga (Jakarta: Balai Pustaka, 2005), h. 26

3 Rian Novianto, Kemilau Bisnis Batu Akik \& Batu Mulia (Yogyakarta: KOBIS, 2015) h. 30

4 Pusat Bahasa, Kamus Besar Bahasa Indonesia edisi ketiga (Jakarta: Balai Pustaka, 2005), h. 162
} 
batu akik dalam bentuk bongkahan tidak merata. Jenis dan kualitas batu akik juga dipengaruhi oleh asal daerah batu akik tersebut. Batu akik bongkahan yang dijualbelikan terdapat juga kemungkinan batu akik bongkahan palsu yang terbuat dari bahan bukan dari batu atau batu akik bongkahan sudah diolah sedemikian rupa agar kualitasnya terlihat menjadi lebih baik, untuk batu akik palsu jenis yang terakhir ini telah menjadi batu akik yang tidak alami lagi karena sudah mendapatkan campur tangan manusia. Untuk lebih menjamin jenis, kualitas dan/atau daerah asal batu terdapat lembaga khusus yang mempunyai ahli gemologist bersertifikat yang tidak hanya dibentuk oleh swasta (misalnya Big Lab, Sky Lab, Gem Research Internasional Lab dan lain-lain) tapi juga dibentuk oleh pemerintah daerah (pemerintah daerah Martapura, Kabupaten Banjar, Kalimantan Selatan, membentuk Unsur Pelaksana Teknis Lembaga Pengembangan dan Sertifikasi BatuMulia dibawah Dinas Perindustrian dan Perdagangan) untuk meneliti melaui gemologist yang akhirnya mengeluarkan hasil berupa sertifikat/ keterangan mengenai batu tersebut. Jual beli batu akik yang sudah jadi dapat dilaksanakan lebih mudah karena kualitas batu yang sudah terlihat dengan jelas tapi berbeda dengan jual beli batu akik dalam bentuk bongkahan karena kualitas batunya ada kemungkinan berbeda antara bagian dalam dan luar batu.

Perjanjian jual beli termasuk perjanjian bernama ${ }^{5}$ karena diatur dan diberi nama oleh pembentuk undang-undang berdasarkan tipe yang paling banyak terjadi sehari-hari yang terdapat dalam Burgerlijk. Wetboek (untuk selanjutnya disebut BW), diatur pada pasal 1457 BW sampai 1540 BW. Pengertian jual beli terdapat pada pasal 1457 BW yaitu suatu perjanjian, dengan mana pihak yang satu mengikatkan dirinya untuk menyerahkan suatu kebendaan, dan pihak yang lain untuk membayar harga yang telah dijanjikan. Perkataan jual beli menunjukkan bahwa dari satu pihak perbuatan dinamakan menjual, sedangkan dari pihak yang lain dinamakan membeli. Istilah yang mencakup dua perbuatan yang bertimbal-balik itu adalah sesuai dengan istilah Belanda "koop en verkoop" yang juga mengandung pengertian bahwa pihak yang satu "verkoopt" (menjual) sedang yang lainnya "koopt" (membeli). Dalam bahasa Inggeris jual-beli disebut

\footnotetext{
5 Mariam Darus Badrulzaman, Hukum Perikatan dalam KUH Perdata (Yurisprudensi, Doktrin serta Penjelasan), buku Ketiga, (Bandung: PT Citra Aditya Bakti, 2015), h. 94
}

dengan hanya "sale" saja yang berarti "penjualan" (hanya dilihat dari sudutnya si penjual), begitu pula dalam bahasa Perancis disebut hanya dengan "vente" yang juga berarti "penjualan", sedangkan bahasa Jerman dipakainya perkataan "Kauf" yang berarti "pembelian". 6

Ikatan jual beli lahir berdasarkan perjanjian para pihak yang berarti juga tunduk kepada aturan terkait perjanjian. Perjanjian merupakan sebuah perikatan ${ }^{7}$ yang lahir karena persetujuan/ kesepepakatan para pihak. BW memberikan pengertian perjanjian pada pasal 1313 BW yaitu Suatu perjanjian adalah suatu perbuatan dengan mana satu orang atau lebih mengikatkan dirinya terhadap satu orang atau lebih. Menurut Tan thong kie Perjanjian jual beli termasuk dalam perjanjian timbal balik (perjanjian yang memberikan kepada masing-masing pihak imbalan yang sama harga atau nilainya). ${ }^{8}$ Untuk menimbulkan perikatan kepada para pihak perjanjian jual beli harus memenuhi empat syarat yang diatur pada pasal 1320 BW$^{9}$ :

a. para pihak telah saling menyatakan kehendak mereka untuk menutup perjanjian (kesepakatan);

b. para pihak cakap melakukan perbuatan hukum (bandelingsbekwaam);

c. sifat dan luas obyek perjanjian dapat ditentukan (bepaalbaar)

d. yang ingin dicapai oleh para pihak memang mungkin dan halal (oorzaak, causa).

Perikatan dapat dirumuskan sebagai hubungan hukum harta kekayaan antara dua orang (atau lebih), di mana pihak yang satu (debitur) wajib melakukan prestasi, sedangkan pihak yang lain (kreditur) berhak atas prestasi itu. ${ }^{10}$

Jual beli batu akik bongkahan yang didasari dengan cacat kehendak tentunya membawa akibat hukum menurut hukum perjanjian.

\footnotetext{
${ }^{6}$ Subekti, Aneka Perjanjian (Bandung: PT Citra Aditya bakti, 2014), h. 1-2

Tiap-tiap perikatan dilahirkan baik karena persetujuan, baik karana undang-undang (Pasal 1233 BW)

8 Tan Thong Kie, Studi Notariat Beberapa Mata Pelajaran dan Serba serbi Praktek. Notaris (PT Ichtiar Baru Van Hoeve: Jakarta, 2007), h. 402

9 J. H. Niewenhuis, Pokok-pokok. Hukum Perikatan, terjemahan Djasadin Saragih (Surabaya: 1985), h. 1

${ }^{10}$ J. H. Niewenhuis, Pokok-pokok Hukum Perikatan, terjemahan Djasadin Saragih (Surabaya: 1985), h. 1
} 


\section{Keabsahan sebuah perjanjian}

Perjanjian jual beli batu bongkahan tidak terlepas dari wilayah aturan hukum yang berlaku agar melindungi kepentingan para pihak. Mengikat atau tidak mengikatnya suatu kontrak ${ }^{11}$ terhadap para pihak yang membuatnya tergantung kepada sah atau tidak sahnya kontrak yang dibuat oleh para pihak tersebut. Sah atau tidak sahnya suatu kontrak dapat dipastikan dengan mengujinya menggunakan instrumen hukum yang terkonkritisasi dalam wujud syarat-syarat sahnya suatu kontrak sebagaimana diatur secara sistematis dalam buku III KUH Perdata, yaitu :

1. Syarat sahnya suatu kontrak sebagaimana diatur dalam Pasal 1320 KUH Perdata

2. Syarat sahnya suatu kontrak sebagaimana diatur di luar pasal $1320 \mathrm{KUH}$ Perdata, yaitu pasal 1335, Pasal 1339 dan Pasal 1347. ${ }^{12}$

Pada Pasal 1320 BW terdapat dua unsur yang berbeda, Pertama, syarat kesepakatan dan kecakapan, merupakan unsur subjektif karena berkenaan dengan diri orang atau subjek yang membuat kontrak. Kedua, syarat objek tertentu dan kausa yang dipebolehkan merupakan unsur objektif. ${ }^{13}$

Terdapat beberapa akibat hukum yang berbeda ketika terjadi pelanggaran terhadap syarat sahnya sebuah perjanjian yang terdapat pada pasal 1320 BW yaitu : Sama sekali tidak timbulnya perjanjian (tidak ada kesepakatan, obyek tertentu, atau causa), atau timbul perjanjian yang demi hukum batal (nietig) (causa yang tidak halal), atau lahir perjanjian, tetapi dapat diganggu gugat (dibatalkan) (tidak cakap, kesesatan, penipuan dan paksaan). ${ }^{14}$

\section{Cacat Kehendak}

Ketika pelaksanaan jual beli batu akik bongkahan dilaksanakan pihak penjual dan pembeli menyatakan kehendaknya masing-masing agar memperoleh kesepakatan (kata sepakat ialah kecocokan antara kehendak/kemauan kedua belah

\footnotetext{
${ }^{11}$ Terdapat beberapa pendapat yang menyatakan pengertian perjanjian/persetujuan sama dengan kontrak.

${ }^{12}$ Muhammad Syaifuddin, Hukum Kontrak, Memahami Kontrak dalam Perspektif filsafat, teori, Dogmatik dan Praktik Hukum (Seri Pengayaan Hukum Perikatan) (Bandung: Mandar Maju, 2012), h. 110

${ }^{13}$ Agus Yudha Hernoko, Hukum Perjanjian: Asas Proporsionalitas dalam Kontrak Komersial (Jakarta: Kencana, 2010), h. 160

${ }^{14}$ J. H. Niewenhuis, Pokok-pokok Hukum Perikatan, terjemahan Djasadin Saragih (Surabaya: 1985), h. 1
}

pihak yang akan mengadakan persetujuan $\left.{ }^{15}\right)$. Bahwa apa yang dikehendaki oleh yang satu itu adalah juga dikehendaki oleh yang lain atau bahwa kehendak mereka adalah "sama", sebenarnya tidak tepat. Yang betul adalah bahwa yang mereka kehendaki adalah "sama dalam kebalikannya". Misalnya : yang satu ingin melapaskan hak miliknya atas suatu barang asal diberi sejumlah uang tertentu sebagai gantinya, sedang yang lain ingin memperoleh hak milik atas barang tersebut dan bersedia memberikan sejumlah uang yang disebutkan itu sebagai gantinya kepada pemilik barang. ${ }^{16}$ Pada pernyataan-pernyataan kehendak yang menghasilkan kesepakatan dibedakan antara penawaran (aanbod, offerte) dan penerimaan (aanvaarding, acceptatie). Penawaran dapat dirumuskan sebagai pernyataan kehendak yang mengandung usul untuk mengadakan perjanjian; unsur ini mencakup esensialia (unsur yang mutlak harus ada, yaitu barang dan harga) $)^{17}$ perjanjian yang ditutup dan pernyataan setuju dari pihak lain yang ditawari berlaku sebagai penerimaan meskipun tidak harus dinyatakan secara tegas namun dapat dengan tingkah laku atau hal-hal lain yang mengungkapkan pernyataan kehendak para pihak untuk melakukan perjanjian. ${ }^{18}$ Dalam kasus jual beli batu akik bongkahan, penawaran yang dilakukan penjual seyogyanya harus dengan jelas dan benar terkait dengan harga dan kualitas batu akik yang menjadi objek jual beli sesuai dengan pengetahuannya tanpa ada yang ditutup tutupi dan misalnya diperlukan dapat ditambahkan bukti lain berupa keterangan mengenai batu tersebut oleh lembaga yang berkompeten dan terpercaya agar pembeli dapat mengetahui kualitas batu akik tersebut sesuai dengan kehendak pembeli. Meskipun pernyataan kehendak tidak diharuskan secara tegas tapi kehendak ini tetap harus ditunjukkan dengan cara yang lain, ketika kehendak atau keinginan disimpan dalam hati, tidak mungkin diketahui oleh pihak lain

${ }^{15}$ R.M. Suryodiningrat, Azas-azas Hukum Perikatan (Bandung: Tarsito, 1995), h. 86

${ }^{16}$ Subekti, Aneka Perjanjian (Bandung: PT Citra Aditya bakti, 2014), h. 3

${ }^{17}$ Selain bagian essensialia dalam sebuah perjanjian juga terdapat bagian naturalia (dalam suatu jual beli jaminan bahwa barang yang dijual tidak cacat dan tergadaikan dan bagian accidentalia (umpamanya dalam hal pemilihan tempat tinggal dan cara pembayaran pada umumnya tergantung para pihak. Lihat Tan Thong Kie hal 406

${ }^{18}$ J. H. Niewenhuis, Pokok-pokok. Hukum Perikatan, terjemahan Djasadin Saragih (Surabaya: 1985), h. 2 
dan karenanya tidak mungkin melahirkan suatu perjanjian. ${ }^{19}$ Pada saat ketika pembeli menyetujui penawaran tersebut maka seketika itulah timbul perikatan diantara mereka. Sesuai dengan asas "konsensualisme" yang menjiwai hukum perjanjian B.W., perjanjian jual beli itu sudah dilahirkan pada detik tercapainya "sepakat" mengenai barang dan harga. Begitu kedua pihak sudah setuju tentang barang dan harga, maka lahirlah perjanjian jual beli yang sah. ${ }^{20} \mathrm{Hal}$ ini sejalan dengan rumusan dalam Pasal 1458 BW yang meyatakan : Jual beli itu dianggap telah terjadi antara kedua belah pihak, seketika setelahnya orang-orang ini mencapai kata sepakat tentang kebendaan tersebut dan harganya, meskipun kebendaan itu belum diserahkan, maupun harganya belum dibayar. Dengan demikian maka yang akan menjadi alat pengukur tentang tercapainya persesuaian kehendak tersebut adalah pernyataan-pernyataan yang telah dilakukan oleh kedua belah pihak. Undang-undang berpangkal pada asas konsensualisme, namun untuk menilai apakah telah tecapai konsensus (dan hal ini adalah maha penting karena merupakan saat lahirnya perjanjian yang mengikat laksana suatu undangundang), kita terpaksa berpijak pada pernyataanpernyataan yang telah dilakukan oleh kedua belah pihak. Dan ini pula merupakan suatu tuntutan kepastian hukum. Bukankah dari ketentuan bahwa kita harus berpijak pada apa yang telah dinyatakan itu timbul perasaan aman pada setiap orang yang telah membuat suatu perjanjian bahwa ia tidak mungkin dituntut memenuhi kehendakkehendak pihak lawan yang tidak pernah dinyatakan kepadanya. ${ }^{21}$ Pernyataan timbal-balik dari kedua belah pihak merupakan sumber untuk menetapkan hak dan kewajiban timbal balik diantara mereka. ${ }^{22}$

Untuk menganalisis adanya dasar keterikatan kontraktual berlandaskan pada kehendak atau pernyataan, menurut Niewenhuis dapat dikaji dari perkembangan tiga teori, yaitu $:^{23}$

\footnotetext{
${ }^{19}$ Subekti, Aneka Perjanjian (Bandung: PT Citra Aditya bakti, 2014), h. 6

${ }^{20}$ Subekti, Aneka Perjanjian (Bandung: PT Citra Aditya bakti, 2014), h. 2

${ }^{21}$ Subekti, Aneka Perjanjian (Bandung: PT Citra Aditya bakti, 2014), h. 6

${ }^{22}$ Subekti, Aneka Perjanjian (Bandung: PT Citra Aditya bakti, 2014), h. 6

${ }^{23}$ Agus Yudha Hernoko, Hukum Perjanjian: Asas Proporsionalitas dalam Kontrak Komersial (Jakarta: Kencana, 2010), h. 165-166
}

a. Teori kehendak (wilsleer; milstheorie), menyatakan bahwa keterikatan kontraktual baru ada hanya jika dan sejauh pernyataan berlandaskan pada putusan kehendak yang sungguh-sungguh sesuai dengan itu. Keberatan terhadap teori ini karena dalam lalu lintas hukum sangat sulit untuk mengetahui apakah pernyataan yang dibuat oleh seseorang itu sesuai dengan kehendaknya. Sehingga selalu menimbulkan pertanyaan apakah ada kepastian hukum mengenai lahirnya keterikatan kontraktual.

b. Teori pernyataan (verklaringsleer; verklaringstheorie), menyatakan bahwa seseorang itu terikat dengan pernyataannya. Kelemahan teori ini apabila terdapat pernyataan yang tidak sesuai dengan kehendak.

c. Teori kepercayaan (vertrouwensleer; vertrounenstheorie), adalah teori baru sebagai ajaran yang diikuti (hersendeleer), merupakan teori jalan tengah yang menjembatani kelemahan dan kekurangan dua teori sebelumnya. Teori ini menyatakan bahwa pernyataan yang menjadi landasan keterikatan kontraktual adalah pernyataan yang selayaknya menimbulkan kepercayaan bahwa hal itu sesuai dengan keputusan kehendak.

Pada dasarnya penawaran dapat dibatalkan (ditarik kembali) sampai saat akseptasi, jadi dengan demikian, dicegah timbulnya perjanjian. ${ }^{24}$ Perjanjian yang dibuat berdasarkan dari kesepakatan (karena bertemunya penawaran dan penerimaan), pada kondisi normal adalah bersesuaian antara kehendak dan pernyataan kedua belah pihak. Namun demikian dimungkinkan bahwa kesepakatan yang dibentuk tersebut berdasarkan cacat kehendak. Perjanjian yang ditutup dibawah pengaruh kesesatan dapat dibatalkan, ${ }^{25}$ Perjanjian jual beli tetap sah karena telah di sepakati oleh para pihak, pihak yang cacat kehendaknya baru mengetahui terdapat ketidaksesuaian tersebut setelah terjadi kesepakatan. Dalam Pasal 1321 BW menyatakan Tiada kata sepakat yang sah apabila sepakat itu diberikan kepada kekhilafan, atau diperolehnya dengan paksaan atau penipuan. Subekti menyatakan kedua belah pihak dalam suatu perjanjian, harus mempunyai kemauan yang bebas untuk mengikatkan diri dan kemauan itu harus dinyatakan, pernyataan ini dapat dilakukan secara tegas atau secara diam-diam, cara yang ${ }^{24}$ J. H. Niewenhuis, Pokok-pokok Hukum Perikatan, terjemahan Djasadin Saragih (Surabaya: 1985), h. 5

${ }^{25}$ J. H. Niewenhuis, Pokok-pokok. Hukum Perikatan, terjemahan Djasadin Saragih (Surabaya: 1985), h. 
belakangan ini sangat lazim dalam kehidupan kita sehari-hari. ${ }^{26}$ Apabila terdapat salah satu dari ketiga unsur tersebut pihak yang merasa dirugikan dapat ngajukan gugatan (penarikan ke muka Hakim / Pengadilan untuk dimintakan penghukuman pada perkara perdata ${ }^{27}$ ) pembatalan perjanjian, sesuai dengan pasal $1449 \mathrm{BW}$.

Perlu dijelaskan secara rinci mengenai tiga hal cacat kehendak tersebut:

\section{A. Kesesatan atau dwaling (vide pasal $1322 \mathrm{BW}$ )}

Terdapat kesesatan apabila terkait dengan "hakikat kebendaan atau orang" dan pihak lawan harus mengetahui bahwa sifat atau keadaan yang menimbulkan kesesatan bagi pihak lain sangat menentukan (terkait syarat dapat dikenali atau diketahui; keenbaarheidsvarieste). Dengan demikian, mengenai kesesatan terhadap hakikat benda yang dikaitkan dengan keadaan yang akan datang, karena kesalahan sendiri atau karena perjanjian atau menurut pendapat umum menjadi resiko sendiri, tidak dapat dijadikan alasan pembatalan kontrak. ${ }^{28}$

Menurut Herlien Budiono, ada dua macam kekeliruan/kesesatan dalam kesesatan membuat kontrak, yaitu :

a. Kekeliruan/kesesatan yang sebenarnya (eigenlijke dwaling) yang merujuk pada situasi kehendak dan pernyataan satu sama lain berkesesuaian, tetapi kehendak satu pihak atau keduanya terbentuk secara cacat, sehingga kontrak yang telah terbentuk dapat dibatalkan, karena terdapat pengaruh kekeliruan/kesesatan. Sebaliknya, jika kekeliruan/kesesatan diketahui sebelumnya, tidak akan terbentuk kontrak, sehingga sepatutnya kontrak dapat dibatalkan. Undang-undang tidak akan menerima alasan adanya kekeliruan/kesesatan tentang situasi atau fakta sebelum dibentuknya kontrak.

b. Kekeliruan/kesesatan yang semu (oneigenlijke dwaling), yang pada prinsipnya tidak akan terbentuk kontrak, karena sebenarnya kata sepakat tidak tercapai. Artinya, syarat ketentuan undang-undang belum terpenuhi mengigat

${ }^{26}$ Subekti, Pokok-pokok Hukum Perdata (Jakarta: Intermasa, 1996), h. 135

${ }^{27}$ Michael R. Purba, Kamus Hukum Internasional \& Indonesia (Jakarta: Widyatama, 2009), h. 163

${ }^{28}$ Agus Yudha Hernoko, Hukum Perjanjian: Asas Proporsionalitas dalam Kontrak Komersial (Jakarta: Kencana, 2010), h. 171 dikutip dalam J. H. Niewenhuis, Pokokpokok. Hukum Perikatan, terjemahan Djasadin Saragih (Surabaya: 1985), h. 12-16 kehendak tidak sejalan dengan pernyataan satu dengan yang lainnya. ${ }^{29}$

B. Paksaan atau dwang (vide Pasal 1323 - 1327 BW)

Paksaan timbul apabila seseorang tergerak untuk menutup kontrak (memberikan kesepakatan) di bawah ancaman yang bersifat melanggar hukum. Ancaman bersifat melanggar hukum ini meliputi dua hal, yaitu :

i. ancaman itu sendiri sudah merupakan perbuatan melanggar hukum (pembunuhan, penganiayaan).

ii. ancaman itu bukan merupakan perbuatan melanggar hukum, tetapi ancaman itu dimaksudkan untuk mencapai sesuatu yang tidak dapat menjadi hak pelakunya. ${ }^{30}$

\section{Penipuan atau bedrog (vide Pasal 1328 BW)}

Penipuan merupakan suatu kesesatan yang dikualifisir (maksud "dikualifisir", artinya memang terdapat kesesatan salah satu pihak, namun ini disengaja oleh pihak lain. Jadi persamaan antara kesesatan dan penipuan adalah adanya pihak yang sesat, sedangkan perbedaannya terletak pada unsur kesengajaan untuk menyesatkan pada penipuan.), artinya ada penipuan bila gambaran yang keliru tentang sifat-sifat dan keadaan-keadaan (kesesatan) yang ditimbulkan oleh tingkah laku yang sengaja menyesatkan dari pihak lawan. Untuk berhasilnya dalil penipuan disyaratkan bahwa gambaran yang keliru itu ditimbulkan oleh rangkaiaan tipu daya (kunstgrepen $^{31}$

Herlien Budiono menjelaskan bahwa penipuan terjadi jika seseorang dengan kehendak dan pengetahuan (willens en wetens) serta kesengajaan (opzet), menyesatkan orang lain, menyembunyikan fakta tertentu, memberikan informasi secara keliru, atau tipu daya lainnya. Dalam hal-hal tertentu, jika

${ }^{29}$ Muhammad Syaifuddin, Hukum Kontrak, Memahami Kontrak dalam Perspektif filsafat, teori, Dogmatik dan Praktik. Hukum (Seri Pengayaan Hukum Perikatan) (Bandung: Mandar Maju, 2012), h. 118 dikutip dari Herlien Budiono, Ajaran Umum Hukum Perjanjian dan Penerapannya di Bidang Kenotariatan (Bandung: PT Citra Aditya Bakti, 2009), h. 98

${ }^{30}$ Agus Yudha Hernoko, Hukum Perjanjian: Asas Proporsionalitas dalam Kontrak Komersial (Jakarta: Kencana, 2010), h. 171 dikutip dalam J. H. Niewenhuis, Pokokpokok Hukum Perikatan, terjemahan Djasadin Saragih (Surabaya: 1985), h. 19

${ }^{31}$ Agus Yudha Hernoko, Hukum Perjanjian: Asas Proporsionalitas dalam Kontrak Komersial (Jakarta: Kencana, 2010), h. 171 dikutip dalam J. H. Niewenhuis, Pokokpokok. Hukum Perikatan, terjemahan Djasadin Saragih (Surabaya: 1985), h. 17 
kesengajaan tidak bersumber dari perbuatannya sendiri, pihak yang tertipu harus membuktikan adanya kesengajaan tersebut. Lebih lanjut, Herlien Budiono menjelaskan bahwa rangkaian fakta yang sama tidak jarang menjadi dasar untuk mengajukan gugatan yang dilandasi adanya penipuan atau kesesatan. Terlepas dari keterkaitan antara kesesatan dan penipuan, di antara keduanya terdapat perbedaan, yaitu : pertama dalam hal penipuan, unsur perbuatan melawan hukum dari pihak yang menipu dan tanggung gugatnya jelas dengan sendirinya, sedangkan dalam kesesatan tidak jelas; kedua, jika terjadi kesesatan masih terbuka kemungkinan mengubah kontrak, tidak demikian dengan halnya penipuan. ${ }^{32}$ Ketika cacat kehendak terjadi karena penipuan, pihak lawan yang merasa kehendaknya tidak sesuai dapat melakukan permohonan gugatan pembatalan perjanjian disertai dengan ganti rugi hal ini dikarenakan pihak yang melakukan penipuan telah melakukan perbuatan melanggar hukum yang membawa kerugian kepada pihak lainnnya, sesuai dengan pasal $1365 \mathrm{BW}^{33}$. Terdapatnya ganti kerugian inilah yang seringkali menjadi dasar pihak yang kehendaknya tidak sesuai seringkali mendalilkan permohonan gugatan kesesatannya disertai dengan penipuan. Untuk berhasilnya pembatalan perjanjian, undangundang mensyaratkan bahwa yang tertipu harus membuktikan bahwa : (1) ada penipuan, dan (2) ia tidak akan membuat perjanjian itu apabila pada saat penandatanganan ia mengetahi adanya penipuan itu. ${ }^{34}$ Unsur pengetahuan para pihak mengenai barang atau orang merupakan salah satu syarat pembatalan sebuah perjanjian.

Perjanjian yang batal akibat adanya paksaan, kekhilafan dan penipuan juga bekibat bahwa barang dan orang-orangnya dipulihkan dalam keadaan sebelum perikatan dibuat, sesuai dengan pasal 1452

\footnotetext{
${ }^{32}$ Muhammad Syaifuddin, Hukum Kontrak, Memahami Kontrak dalam Perspektif filsafat, teori, Dogmatik dan Prak.tik Hukum (Seri Pengayaan Hukum Perikatan) (Bandung: Mandar Maju, 2012), h. 118 dikutip dari Herlien Budiono, Ajaran Umum Hukum Perjanjian dan Penerapannya di Bidang Kenotariatan (Bandung: PT Citra Aditya Bakti, 2009), h. 99

33 Tiap perbuatan Melanggar hukum, yang membawa kerugian kepada orang lain, mewajibkan orang yang karena salahnya menerbitkan kerugian itu, mengganti kerugian tersebut.

${ }^{34}$ Tan Thong Kie, Studi Notariat Beberapa Mata Pelajaran dan Serba serbi Praktek Notaris (PT Ichtiar Baru Van Hoeve: Jakarta, 2007), h. 409
}

BW. Pengertian keadaan sebelum perikatan dibuat disini adalah bahwa segala apa yang telah diberikan atau dibayarkan kepada orang-orang sebagai akibat perikatan hanya dapat dituntut kembali apabila barangnya masih berada ditangan orang tersebut atau ternayata telah mendapat manfaat dari apa yang telah diberikan atau dibayarkan atau bahwa apa yang dinikmati telah dipakai atau berguna bagi kepentingannya. Apabila barang tersebut sudah berkurang nilainya maka nilainya tersebutlah yang diperhitungkan untuk dikembalikan. ${ }^{35}$ Tuntutan pembatalan perjanjian karena adanya paksaan, kekhilafan atau penipuan berlaku paling lambat 5 (lima) tahun setelah pihak yang merasa dipaksa, khilaf atau tertipu mengetahui adanya hal tersebut ${ }^{36}$, melewati batas tersebut maka pihak yang dipaksa. khilaf atau ditipu dianggap secara tegas atau diamdiam menyetujui adanya kesepakatan diantara mereka dan tidak bisa lagi menuntut adanya pembatalan perjanjian ${ }^{37}$.

Kualitass batu akik bongkahan memang tidak bisa dipastikan karena terdiri dari beberapa lapisan dan/atau beberapa elemen, sehingga untuk perjumpaan kehendak para pihak harus dilaksanakan dengan sebagaimana mestinya. Pembeli pastinya meinginkan mendapatkan batu akik yang berkualitas terbaik sedangkan penjual menginkan harga jual yang tertinggi.

\section{Contoh kasus}

- Kasus pertama, bahwa diketahuiya kualitas batu akik bongkahan bagian luar lebih baik kualitasnya daripada bagian dalamnya sebelum terjadi kesepakatan.

Penjual dan pembeli mengetahui ada perbedaan kehendak sebelum mencapai kesepakatan sehingga belum timbul perikatan maka perjanjian jual beli tersebut langsung dapat dibatalkan.

Kasus kedua, bahwa diketahuinya kualitas batu akik bongkahan bagian luar lebih baik kualitasnya daripada bagian dalamnya setelah terjadi kesepakatan.

Penjual yang tidak mengetahui bahwa bagian luar batu akik bongkahan lebih baik dari yang didalam dan telah memberitahukan kepada pembeli sebelum perjanjian tetapi tetap melaksanakan perjanjian jual beli maka perjanjian tidak dapat dibatalkan karena cacat karena kedua belah pihak

\footnotetext{
${ }^{35}$ Pasal 1451 BW

36 Pasal 1454 BW

${ }^{37}$ Pasal 1456 BW
} 
melakukan penawaran dan penerimaan terhadap batu akik tersebut dengan telah menyampaikan kehendak masing-masing. Berbeda ketika penjual mengetahui bahwa batu akik bongkahan bagian luarnya lebih baik dari yang di dalam dengan sengaja tidak memberitahukannya atau memberikan informasi pada saat penawaran menyatakan bahwa batu akik bongkahan tersebut memiliki kualitas yang sama antara bagian luar dan dalam maka pembeli dapat melakukan pembatalan perjanjian disertai gugatan ganti rugi karena sudah terdapat unsur penipuan.

- Kasus ketiga, bahwa diketahuinya kualitas batu akik bongkahan bagian dalam lebih baik kualitasnya daripada bagian luarnya setelah terjadi kesepakatan.

Penjual batu akik tidak bisa membatalkan perjanjian karena kesalahannya sendiri salah menilai kualitas batu akik bongkahan tersebut.

\section{Penutup}

Batu akik bongkahan mempunyai jenis, kualitas dan/atau asal daerah yang beragam. Dalam pelaksanaan perjanjian jual beli batu akik bongkahan kehendak para pihak tentunya mendapatkan yang terbaik dari jual beli batu bongkahan tersebut. Pembeli menghendaki mendapatkan batu akik bongkahan yang jenis, kualitas dan/atau asal daerahnya sesuai dengan kehendaknya yang disampaikan kepada penjual, penjual menawarkan batu akik bongkahan sesuai dengan pengetahuannya terkait dengan jenis, kualitas dan/atau asal daerah batu akik bongkahan tersebut. Ketika timbul cacat kehendak antara kehendak antara pembeli dan penjual terkait jenis, kualitas dan/atau asal daerah batu akik bongkahan yang merupakan hakikat benda dalam perjanjian jual beli tersebut diketahui sebelum terjadi kesepakatan maka perjanjian tersebut dapat langsung dibatalkan kedua belah pihak, apabila telah terjadi kesepakatan maka perjanjian tersebut dapat dibatalkan oleh pihak yang merasa kesepakatannya tidak sesuai dengan kehendakknya (cacat kehendak) kecuali cacat kehendak tersebut terdapat unsur kesalahan sendiri, karena sudah diperjanjikan terlebih dahulu, karena pendapat umum menyatakan hal tersebut merupakan resiko sendiri atau hakikat benda yang dikaitkan dengan keadaan yang akan datang, apabila kesesatan (gambaran keliru tentang sifatsifat dan keadaan-keadaan) tersebut ditimbulkan oleh tingkah laku yang sengaja dari pihak lawan maka sudah termasuk dalam penipuan yang dimana pihak yang merasa cacat kehendaknya dirugikan dapat menggugat pembatalan perjanjian disertai dengan gugatan ganti rugi karena telah melakukan perbuatan melanggar hukum.

\section{Daftar Pustaka}

Darus Badrulzaman, Mariam. 2015. Hukum Perikatan dalam KUH Perdata (Yurisprudensi, Doktrin serta Penjelasan), buku Ketiga. Bandung: PT Citra Aditya Bakti.

H. Niewenhuis, J. 1985. Pokok-pokok Hukum Perikatan, terjemahan Djasadin Saragih. Surabaya.

M. Suryodiningrat, R. 1995. Azas-azas Hukum Perikatan. Bandung: Tarsito.

Novianto, Rian. 2015. Kemilau Bisnis Batu Akik \& Batu Mulia. Yogyakarta: KOBIS.

Pusat Bahasa. 2005. Kamus Besar Bahasa Indonesia edisi Ketiga. Jakarta: Balai Pustaka.

R. Purba, Michael. 2009. Kamus Hukum Internasional \& Indonesia. Jakarta: Widyatama.

Subekti, R dan R. Tjitrosudibio. 2006. Kitab Undangundang Hukum Perdata. Jakarta: PT Pradnya Paramita.

Subekti, R. 1996. Pokok-pokok Hukum Perdata. Jakarta: Intermasa.

2014. Aneka Perjanjian. Bandung: PT Citra Aditya bakti.

Syaifuddin, Muhammad. 2012. Hukum Kontrak, Memahami Kontrak dalam Perspektif filsafat, teori, Dogmatik dan Praktik Hukum (Seri Pengayaan Hukum Perikatan). Bandung: Mandar Maju.

Syaifuddin, Muhammad. 2012. Hukum Kontrak, Memahami Kontrak dalam Perspektif filsafat, teori, Dogmatik dan Praktik. Hukum (Seri Pengayaan Hukum Perikatan). Bandung: Mandar Maju. Dikutip dalam Herlien Budiono. 2009. Ajaran Umum Hukum Perjanjian dan Penerapannya di Bidang Kenotariatan. Bandung: PT Citra Aditya Bakti.

Thong Kie, Tan. 2007. Studi Notariat Beberapa Mata Pelajaran dan Serba serbi Praktek. Notaris. Jakarta: PT Ichtiar Baru Van Hoeve.

Yudha Hernoko, Agus. 2010. Hukum Perjanjian: Asas Proporsionalitas dalam Kontrak Komersial. Jakarta: Kencana. 